\title{
Environmental health in slum communities \\ Analysis of household water quality in four slum communities in the City of Bhuj, India
}

\section{Fiona Wieland, Basel}

\section{Introduction}

The environment in which we live greatly affects our health. To stay healthy, the water we drink, the air we breathe and the food we eat must be clean, wholesome and/or free from contamination. A good environment is, thus, most relevant for our well-being. However, especially in slum communities, environmental health conditions are particularly bad. Both the natural and the built environment are not free from undue hazard. In many cases, essential environmental services, such as adequate sanitation facilities, water supply and solid waste management, are not provided to households and communities.

However, the poor are vulnerable not only because of where they live, but also due to the work they do, the greater risks they run and their lower resistance to infections. 1.1 billion people worldwide do not have access to a safe water supply and 2.4 billion lack adequate sanitation (WoRld HEALTH ORganization 2001: 6). As is illustrated in Fig. 1, many diseases may be linked to an inadequate water and sanitation situation.

Environmental health focuses on all aspects related to health. When poor people get ill, they lose their income and in many cases, also their jobs. Environmental health interventions, such as improved water supply, drainage and sanitation are known to improve the health situation of poor communities. For the poor, however, health is often only a minor benefit of such improvements. The main benefits frequently are about saving time (e.g. from water collection), reducing the burden of daily life, lowering the basic cost of living, supporting the emancipation of women, promoting dignity, self-respect and safety, creating a more pleasant and ordered living space and raising income. Additionally, environmental health can contribute to national and regional education goals: diseases keep children away from school, not only when they are ill themselves, but also when they have to work instead of their ill parents. The lack of environmental services at schools, particularly with regard to sanitation and water supply, is also an important determinant to school registration of girls, especially after puberty (CAIRNCROSS \& KOLSKY 2003: 1-3).

\section{Research focus}

The article presents results of a sub-project within the research project «GIS-based slum monitoring for mitigating poverty, vulnerability and disease in urban slums», led by the Urban and Regional Studies Unit of the Institute of Geography, University of Basel, Switzerland, and the All India Disaster Mitigation Institute in Ahmedabad (AIDMI), India. The study area is built by four selected slum communities in the City of Bhuj, notably Jayprakashnagar, Shantinagar, Bhimraonagar and Mustuffanagar.

The main research objective was to determine key variables affecting the water quality of the surveyed households. These variables may have a demographic, social or financial character or concern environmental services. Thus, attention was paid in particular to the following aspects:

- The description of the prevailing water supply, sanitation and hygiene situation within the four surveyed slum communities.

- The creation of maps to show the spatial distribution of the drinking water quality in the four surveyed slums.

- The identification of indicator variables for the water quality and of areas with urgent drinking water problems.

- The specification of the action to be taken and the areas of application.

The analyses took place at both the micro and the macro level. Thus, data was evaluated at both household level and slum level. This enabled a clear comparison of the four surveyed slum communities.

\section{Methods}

\subsection{Spatial information and questionnaire}

In order to create a spatial information basis, the slum areas were systematically mapped in the field and visually presented using Geographic Information System (GIS).

Empirical data was collected by means of a standardised questionnaire by AIDMI and the Geographical Institute of the University of Basel. The target population consisted of all households within the four slum communities selected. Thus, all households, except the ones, which were not available or refused cooperation, 


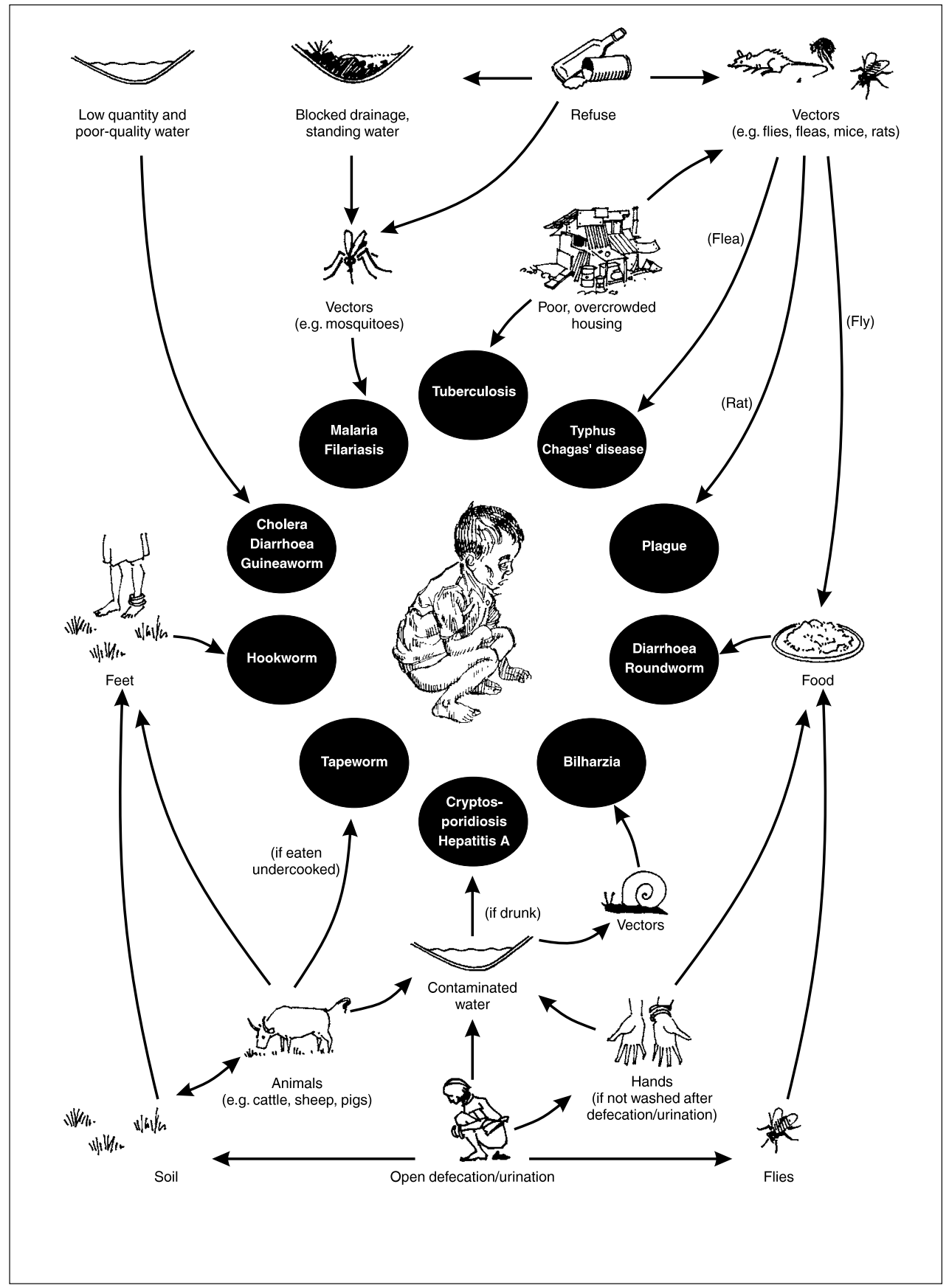

Fig. 1: Water and sanitation related diseases

Krankheiten mit Bezug zur Situation der Trinkwasserversorgung und der sanitären Einrichtungen Maladies en rapport avec l'eau potable et les conditions sanitaires

Source: Water Engineering Development Centre (WEDC) 1999: 74; www. lboro.ac.uk/well/resources/technical-briefs/technical-briefs.htm 
were interviewed. Of the 657 households recorded, 497 participated in the survey.

\subsection{Water analysis}

As faecal contamination is often considered a major health risk in association with small-community water supplies, particular attention was given to water quality analysis. Micro-biological analysis of the drinking water was carried out to determine the hygienic quality of the water supply. This examination required the isolation and enumeration of organisms that indicate the presence of faecal contamination. E.coli is a good indicator organism for assessing this particular form of drinking water contamination. Its use as indicator is especially suitable if resources for microbiological examination are limited. The portable DelAgua field test kit from Oxfam, which works with the membrane filter method, allows analysis of E.coli even under difficult field conditions. Other methods, such as the multiple tubes method or the presence-absence test were not considered suitable for the dominant conditions (SANitATION IN DEVEloping CoUnTRIES 2002: 13).

For membrane filtration, a minimum sample volume of $10 \mathrm{ml}$ is introduced aseptically into a sterile or properly disinfected filtration assembly containing a sterile membrane filter with a nominal pore size of 0.2 or $0.45 \mathrm{Mm}$. The volume to be filtered strongly depends on the degree of pollution. The World Health Organization (WHO) recommends a standard volume of $100 \mathrm{ml}$ in its guidelines for safe drinking water. But, if for example water of a river is examined, a dilution of the sample is meaningful. In surface water in particular, a high degree of pollution can be expected, making countability of bacteria colonies in non-diluted solutions problematic.

By means of vacuum, the sample is drawn through the membrane filter. This allows all indicator organisms to be retained on or within the filter. The filter is then transferred to a suitable selective culture medium in a petri dish. The petri dish is transferred to an incubator set at an appropriate temperature. There it is incubated for a determined time to allow the indicator organisms to mulitply. Thus, visually identifiable and countable colonies are formed. The result is expressed in «number of colonies forming units» (CFU) per $100 \mathrm{ml}$ of original sample (World Health OrganizaTION 1997: 60, 61).

In addition to the analysis of the faecal contamination, the turbidity, the $\mathrm{pH}$ value and the amount of chlorine residual were tested. The amount of suspended matter in the water is an important aspect to be taken into consideration when applying disinfectants. High water turbidity could prevent the micro organisms from getting attacked by the disinfecting agent. The acidity of the water ( $\mathrm{pH}$ value), on the other hand, influences the effectiveness of disinfection by chlorine and other chemical solutions. Specifically, $\mathrm{pH}$ values above 8 reduce the ability of a chlorine disinfectant to eliminate germs. Where water has been disinfected by chlorine, there should be a small amount of residual chlorine in the water to protect it against recontamination. If this amount is too high, it could harm the consumer's health.

\section{Results and discussion}

\subsection{Water quality situation at slum level}

A comparison of the tested water samples by slum community adds a spatial dimension for the large differences in quality.

Although drinking water in the Jaypragashnagar slum community was particularly highly contaminated, overall water quality in Shantinagar was alarming. Such high concentrations of E.coli bacteria can be explained by a very poor quality of water supplies or a lack of sanitary drinking water handling. In fact, it is likely that both of the above apply here. The results show that immediate interventions are necessary in these slum communities.

The water samples from the Bhimraonagar and Mustuffanagar slum communities also indicated a contamination with E.coli bacteria. Although the levels found here are still very harmful for human health, compared to the concentrations found in the other two slums, they were relatively low (maps 14).

In order to examine whether dependencies between a household's water quality and demographic, social or financial factors exist, water samples from around 100 households spread over the four slum areas were taken and analysed.

\subsection{Water quality situation at household level}

Neither the results of the $\mathrm{pH}$ analysis nor the turbidity testing appeared particularly alarming: the $\mathrm{pH}$ value of the tested water samples ranged from 6.5$7 \mathrm{pH}$. These results lie within the normal range for water and thus indicate more or less neutral conditions (neither acidic nor alkaline). The turbidity of the tested water samples was light with only five samples showing a turbidity higher than 5 NTU (Nephelometric Turbidity Units).

On the other hand, water quality testing revealed greater differences, particularly with regards to the amount of E.coli bacteria in the water (Tab. 1). 


\begin{tabular}{|r|c|c|c|}
\hline \multicolumn{4}{|c|}{ E.coli bacteria per $100 \mathrm{ml}$} \\
\hline & Frequency & $\begin{array}{c}\text { Valid } \\
\text { percentage }\end{array}$ & $\begin{array}{c}\text { Cumulative } \\
\text { percentage }\end{array}$ \\
\hline 0 & 12 & 13.6 & 13.6 \\
$<10$ & 16 & 18.2 & 31.8 \\
$10-70$ & 15 & 17.0 & 48.9 \\
$71-100$ & 10 & 11.4 & 60.2 \\
$101-200$ & 8 & 9.1 & 69.3 \\
$201-450$ & 10 & 11.4 & 80.7 \\
$451-1000$ & 6 & 6.8 & 87.5 \\
$1001-2000$ & 7 & 8.0 & 95.5 \\
$>2000$ & 4 & 4.5 & 100.0 \\
\hline Total & 88 & 100.0 & \\
\hline
\end{tabular}

Tab. 1: Simple frequency of E.coli bacteria Einfache Häufigkeit der E.coli Bakterien Fréquence simple de la bactérie E.coli Source: University of BASEl, Institute of Geography, Urban and Regional Studies, and All India Disaster Mitigation Institute, Ahmedabad, India (2005): Social Science Survey in four slum communities in the City of Bhuj

Of 88 households tested, only $13.6 \%(n=12)$ had access to a water quality of 0 E.coli bacteria/100 ml, which is in conformity with the World Health Organization guidelines for clear drinking water. Worded differently, only the water of 12 households satisfied the standards set by the WHO for drinking water. The water of the other households appeared to be officially unacceptable for consumption. Even here, the differences in the quality of drinking water samples vary greatly. $46.6 \%$ $(n=41)$ of the tested water samples had maximum 100 E.coli bacteria/100 ml, enough to be considered of «intermediate risk» by WHO standards. $27.3 \%$ of the tested water samples contained between 100 and 1000 E.coli bacteria per $100 \mathrm{ml}$, thus making them of «high risk» for human health. 11 households $(12.5 \%)$ were found to be consuming drinking water with over 1000 E.coli/100 ml (very high risk) (World Health OrganIZATION 1997: 78).

These results show that most of the families living in the four surveyed slum communities daily consume water with a great amount of E.coli bacteria. The presence of these bacteria indicates a faecal contamination of the water. Specific diseases like diarrhoea, cholera and typhoid, which can be transmitted over water are called faecal-oral diseases. They represent the most common water related diseases (World Health ORGANIZATION 2002: 127).

\subsection{Water treatment methods}

In light of the alarming water quality results, water samples were analysed according to undergone purification treatment, if any.

Of 77 households analysed (11 households did not indicate their treatment method), $72.7 \%$ appear to filter their drinking water through a piece of cloth before consumption. Only five households $(6.5 \%)$ boil their water before drinking and $26 \%$ of the households do not treat their water at all (Tab. 2).

The number of E.coli bacteria found in the water samples treated by cloth differs greatly. Even though 17.3\% of the water samples have no E.coli bacteria and 59.6\% have less than 100 E.coli bacteria per $100 \mathrm{ml}, 40.4 \%$ of the filtered water samples still have more than 100 E.coli bacteria per $100 \mathrm{ml} .15 .4 \%$ of the water samples are even of particularly high risk with about 450 to over 2000 E.coli bacteria per $100 \mathrm{ml}$ (Tab. 3, p. 120 in this article).

This high variation shows that filtration by cloth cannot be regarded as a safe water treatment method. A family using this method to «clean» its drinking water may not be sure of drinking safe water after the treatment. Either the method does not effectively rid water of these particular germs or recontamination of water after treatment has to be taken into account. However, it cannot be taken for granted that $82.7 \%$ of the E.coli bacteria pollution came from recontamination by the consumers alone. To argue that recontamination is the main cause would be to imply that all other treatment methods have a similar risk or recontamination is linked to a particular water treatment method.

\begin{tabular}{|l|r|r|r|}
\hline Treatment & Frequency & $\begin{array}{c}\text { Valid } \\
\text { percentage }\end{array}$ & $\begin{array}{c}\text { Cumulative } \\
\text { percentage }\end{array}$ \\
\hline Filtration by cloth & 52 & 67.5 & 67.5 \\
Boiling & 1 & 1.3 & 68.8 \\
Filtration by cloth & 4 & 5.2 & 74.0 \\
and boiling & 20 & 26.0 & 100.0 \\
No treatment & 77 & 100.0 & \\
\hline Total & & & \\
\hline
\end{tabular}

Tab. 2: Simple frequency of water treatment methods Einfache Häufigkeit der Reinigungsmethoden Fréquence simple des méthodes de traitement de l'eau Source: University of BASEl, Institute of Geography, Urban and Regional Studies, and All India Disaster Mitigation Institute, Ahmedabad, India (2005): Social Science Survey in four slum communities in the City of Bhuj 


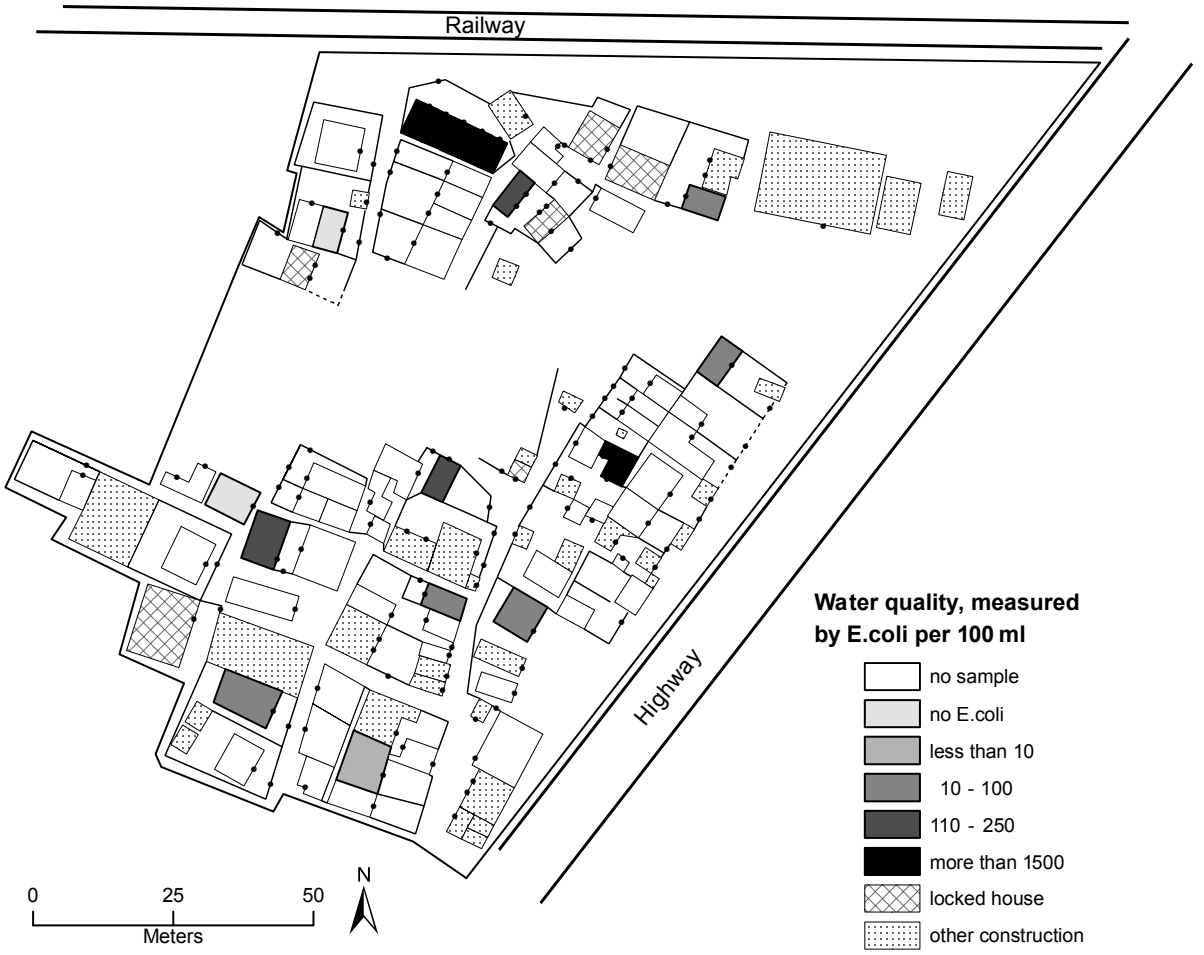

Map 1: Quality of household drinking water in the Jayprakashnagar slum community, City of Bhuj, India The categories in maps 1-4 include breaks to represent the gaps in the number of E.coli per $100 \mathrm{ml}$. Thus, use was made here of the natural breaks classification method.

Qualität des Trinkwassers in der Slum Community Jayprakashnagar, Bhuj, Indien

Qualité de l'eau potable des ménages du bidonville de Jayprakashnagar à Bhuj, Inde

Source: University of Basel, Institute of Geography, Urban and Regional Studies, and All India Disaster Mitigation Institute, Ahmedabad (2005): Slum mapping, map verification and social science survey in slum communities of the City of Bhuj, Gujarat, India; base map: UNIVERSITY OF BASEL, INSTITUTE OF GEOGRAPHY, URBAN and Regional Studies, digital map based on IKONOS-satellite image of the City of Bhuj, dated 20/12/2003 (European Space Imaging GmbH); cartography: F. Wieland

To get a general idea of the effectiveness of other treatment methods, isolated tests were carried out. Thus, in addition to the household water samples taken, specific samples from community wells and hand pumps were collected. From each of these external sources, three water samples were taken. One was tested without treating, the second was treated with Micropur Forte (chlorination pill for water treatment) and the last sample was exposed to sunlight by using SODIS, which is a low-cost water treatment method using the solar energy to disinfect microbiologically contaminated raw water (Swiss Federal InStitute of Aquatic Science And Technology 2005) (Fig. 2).

Compared to the results of cloth filtration, which showed a highly diverging water quality, the treatment by chlorination and SODIS showed satisfying results. Both methods eliminated the existing germs in all tested water samples with an efficiency of $100 \%$. But as the chlorination products are quite expensive, their amount has to be adapted to the degree of contamination and they leave a bad aftertaste to the water, the SODIS method seems to be the most appropriate method to be used in slum community households. Pet bottles are locally available, the needed insolation is mostly given and water with a high turbidity can be filtered before (Fig. 3).

4.4 Impact of demographic, social or financial factors In order to determine key variables to explain a household's water quality, the results of the water analysis 


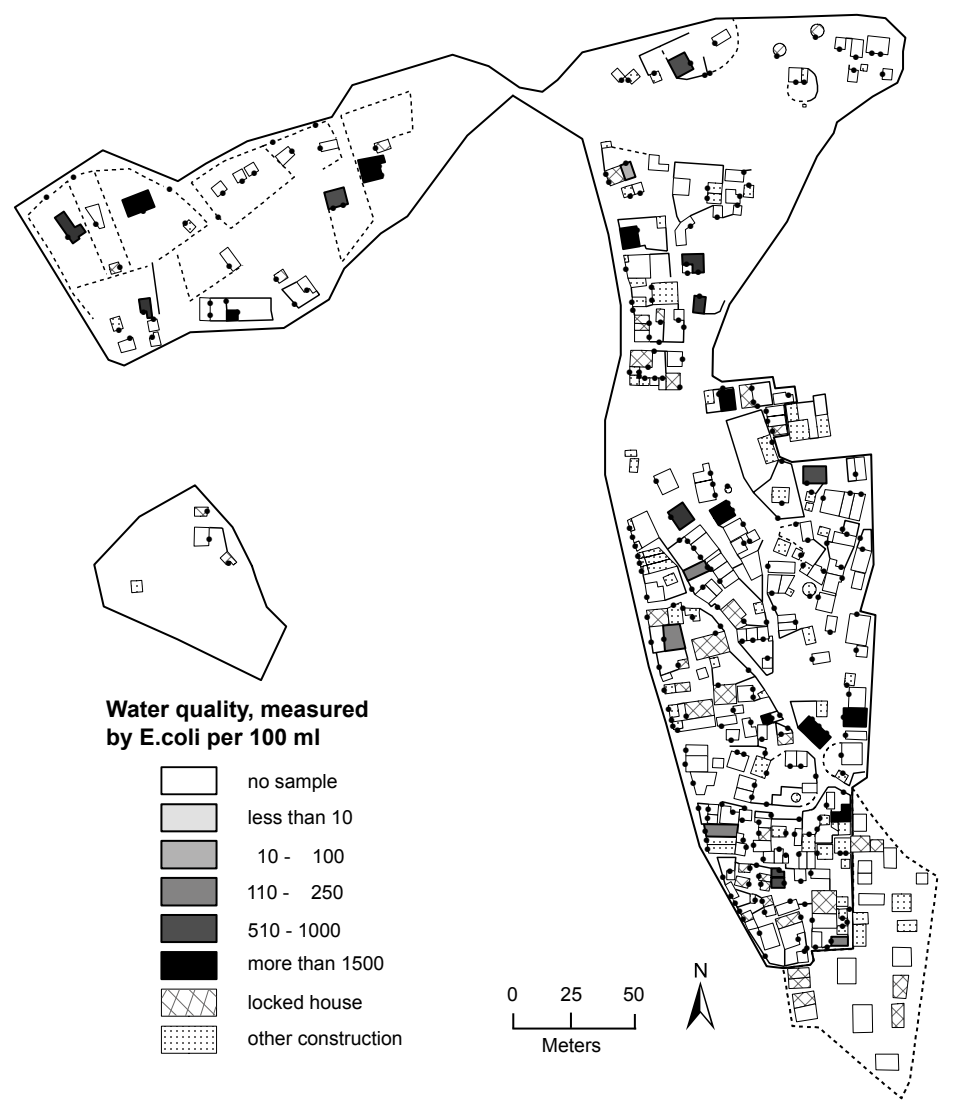

Map 2: Quality of household drinking water in the Shantinagar slum community, City of Bhuj, India Qualität des Trinkwassers in der Slum Community Shantinagar, Bhuj, Indien

Qualité de l'eau potable des ménages du bidonville de Shantinagar à Bhuj, Inde

Source: University of Basel, Institute of Geography, Urban and Regional Studies, and All India Disaster Mitigation Institute, Ahmedabad (2005): Slum mapping, map verification and social science survey in slum communities of the City of Bhuj, Gujarat, India; base map: UnIVERSITY of BASEL, INSTITUTE OF GEOGRAPHY, URBAN and Regional Studies, digital map based on IKONOS-satellite image of the City of Bhuj, dated 20/12/2003 (European Space Imaging GmbH); cartography: F. Wieland

were compared with different demographic, social and financial factors and with prevailing environmental services - information that had been gained from the Social Sciences Survey of 2005 by the University of Basel.

On the whole, it appears that a household's water supply and sanitation situation is affected more by financial security than by social environment. The only social factor, which shows a constant trend in relation to tested water quality, is the «number of family members». The more members a family has, the worse the drinking water quality gets. However, this trend depends more on a certain threshold value than minimal differences of one or two family members; when a certain household size is exceeded, the water quality deteriorates. This could be explained by increasing risk of recontamination as the number of family members increases, or by the weaker financial situation of a larger family.

Indeed, the relation between household water quality and total family monthly income appears significant. In a household with high financial security, the willingness to invest in water supply and sanitation facilities 


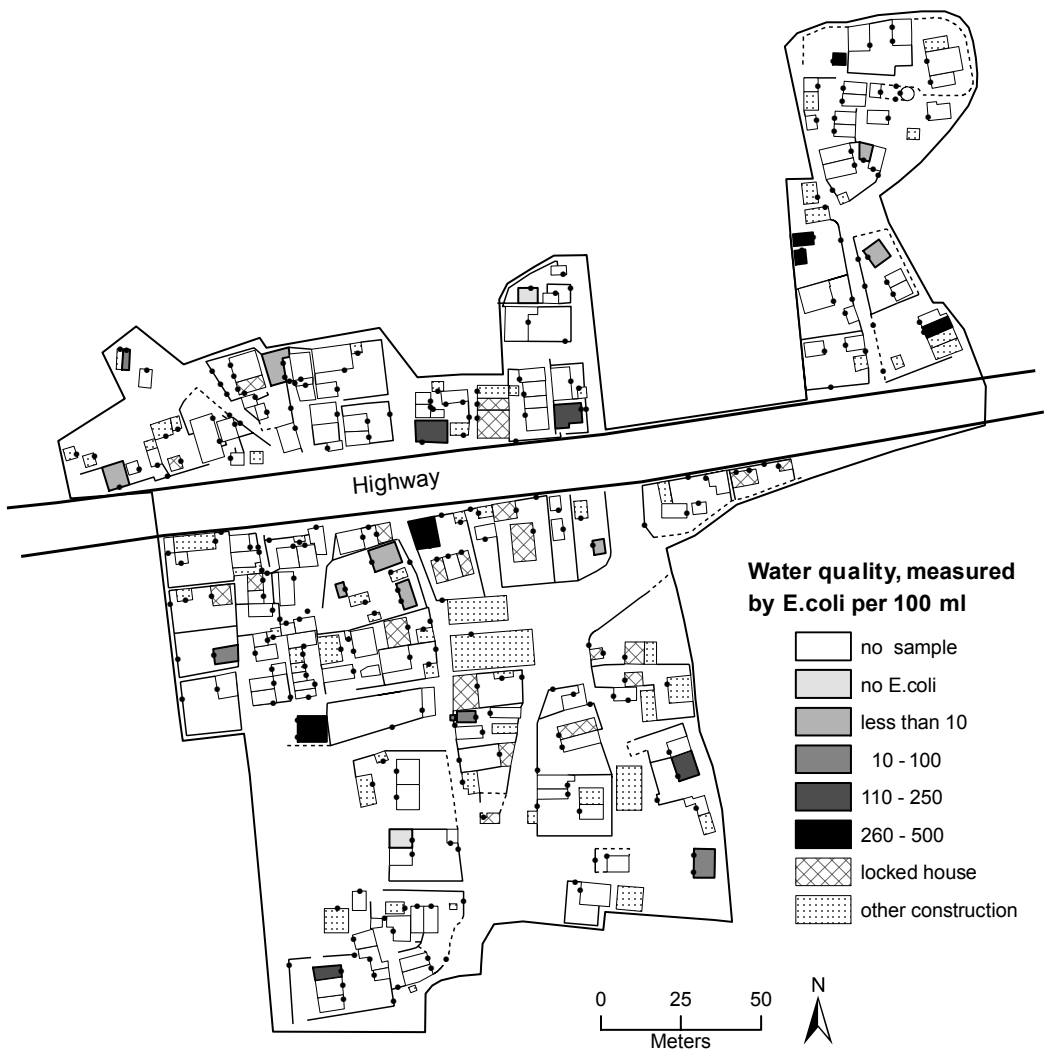

Map 3: Quality of household drinking water in the Bhimraonagar slum community, City of Bhuj, India Qualität des Trinkwassers in der Slum Community Bhimraonagar, Bhuj, Indien

Qualité de l'eau potable des ménages du bidonville de Bhimraonagar à Bhuj, Inde

Source: University of Basel, Institute of Geography, URban and Regional Studies, and All India Disaster Mitigation Institute, Ahmedabad (2005): Slum mapping, map verification and social science survey in slum communities of the City of Bhuj, Gujarat, India; base map: UnIVERSITY of BASEL, INSTITUTE OF GEOGRAPHY, URBAN and Regional Studies, digital map based on IKONOS-satellite image of the City of Bhuj, dated 20/12/2003 (European Space Imaging GmbH); cartography: F. Wieland

increases noticeably. Of further relevance could be the relation between high monthly income and higher education degrees of family heads (Tab. 4).

The higher the education level of the family head, the better the awareness of relations between environmental health and personal health. The results show a high coherence between the awareness of these facts and the water quality found in the family (Tab. 5).

The better water quality of families with a higher income can therefore be explained by their higher education standard and greater awareness of environmental influences, in addition to a greater willingness to invest in improving their personal water and sanitary situation. Particularly the last aspect has a direct influence on improving a family's health situation.

\section{Implications}

The results of the study point out three areas of action and approaches to solutions.

\subsection{Water supply and sanitation situation improvement} The water supply and sanitation situation in the surveyed slum communities is insufficient. Many households do not have access to a private water source and 


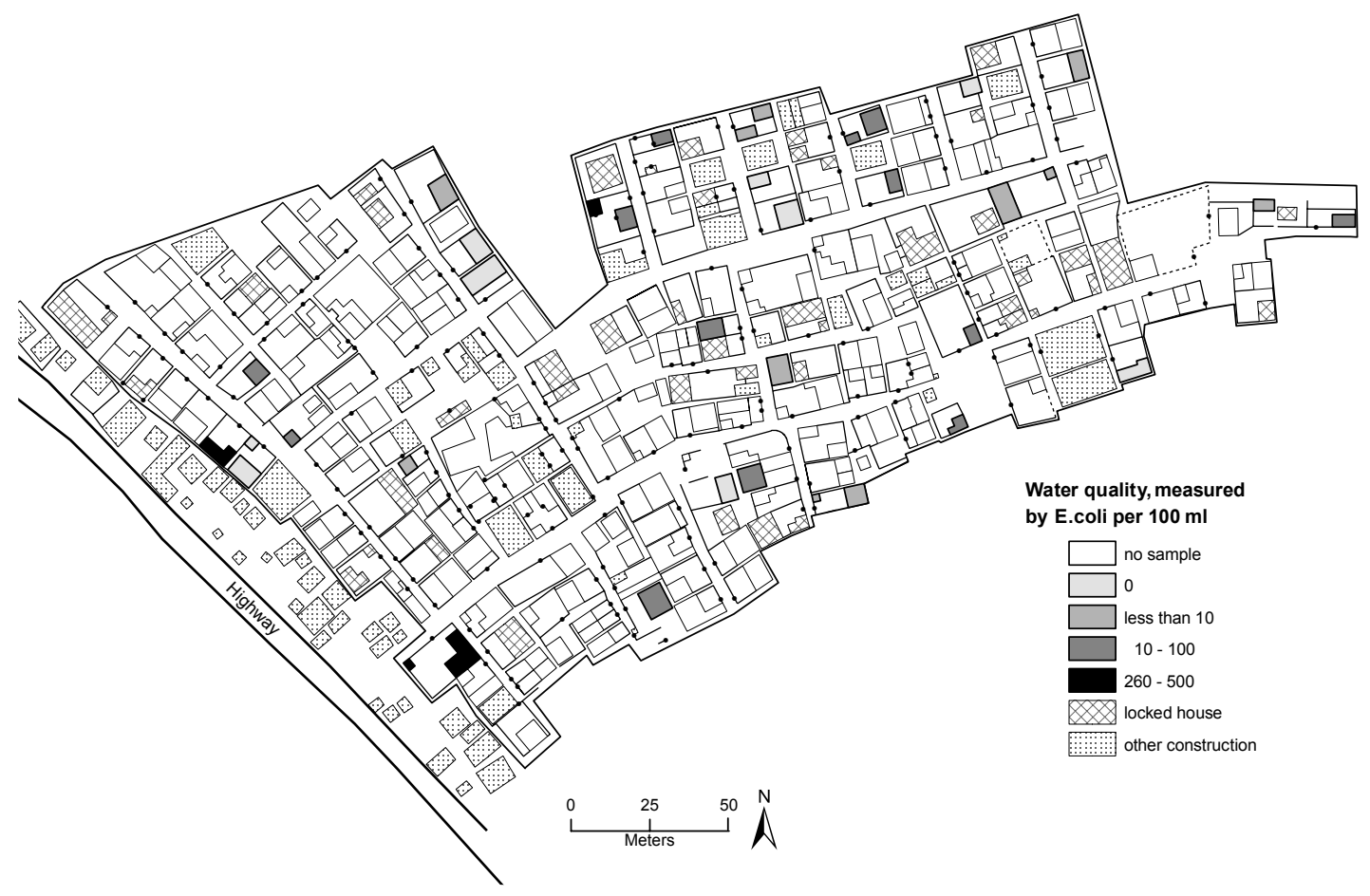

Map 4: Quality of household drinking water in the Mustuffanagar slum community, City of Bhuj, India Qualität des Trinkwassers in der Slum Community Mustuffanagar, Indien

La qualité de l'eau potable des ménages du bidonville de Mustuffanagar à Bhuj, Inde

Source: University of Basel, Institute of Geography, Urban and Regional Studies, and All India Disaster Mitigation Institute, Ahmedabad (2005): Slum mapping, map verification and social science survey in slum communities of the City of Bhuj, Gujarat, India; base map: UnIVERsity of BASEL, INSTITUTE OF GEOGRAPHY, URBAN and Regional Studies, digital map based on IKONOS-satellite image of the City of Bhuj, dated 20/12/2003 (EuRopean Space Imaging GmbH); cartography: F. Wieland

even more households do not have a private toilet facility. The family members have to spend a lot of their time for water collection and are forced to defecate in the open space around the slum area. But even if some households have private toilet facilities they mostly are not connected to an adequate sewerage system.

It is therefore unsurprising that the water quality tests showed an insufficient overall drinking water quality in the four surveyed slum communities. Only $31.8 \%$ of the tested households could consume their water safely or with low health risks. The remaining households consumed drinking water which was highly contaminated with E.coli bacteria, raising their risk of infection by various diseases. Although the drinking water provided by private taps has a better quality than the water from public wells and hand pumps, it does not satisfy the WHO guidelines for drinking water and should not be consumed untreated.

Poor environmental health, personal health and poverty are inseparably connected to each other; they build a vicious circle. Unsafe drinking water and inadequate sanitation facilities, or poor environmental health services in general, increase the risk of illness. Poverty may increase personal and environmental risks, increase malnutrition and lower the access to education. Ill persons, in particular, have a diminished quality of living, are less productive, have a lowered learning ability, reduced household savings or increased debts and are therefore forced to live under poor conditions. Improvements in this area are of vital importance as they build the fundament for better living conditions in slum communities and enable an individual disease protection. 


\begin{tabular}{|r|c|c|c|}
\hline \multicolumn{2}{|c|}{ E.coli bacteria per $100 \mathrm{ml}$} & \\
\hline & Frequency & $\begin{array}{c}\text { Valid } \\
\text { percentage }\end{array}$ & $\begin{array}{c}\text { Cumulative } \\
\text { percentage }\end{array}$ \\
\hline 0 & 9 & 17.3 & 17.3 \\
$<10$ & 10 & 19.2 & 36.5 \\
$10-70$ & 9 & 17.3 & 53.8 \\
$71-100$ & 3 & 5.8 & 59.6 \\
$101-200$ & 6 & 11.5 & 71.2 \\
$201-450$ & 7 & 13.5 & 84.6 \\
$451-1000$ & 4 & 7.7 & 92.3 \\
$1001-2000$ & 3 & 5.8 & 98.1 \\
$>2000$ & 1 & 1.9 & 100.0 \\
\hline Total & 52 & 100.0 & \\
\hline
\end{tabular}

Tab. 3: Simple frequency of water quality when filtering by cloth

Einfache Häufigkeit der Qualität gefilterter Wasserproben

Fréquence simple de la qualité des eaux filtrées par du tissu

Source: University of Basel, Institute of Geography, Urban and Regional Studies, and All India Disaster Mitigation Institute, Ahmedabad, India (2005): Social Science Survey in four slum communities in the City of Bhuj

\subsection{Raise awareness of links between environmental health and personal health through workshops and education efforts}

The second area of action concerns education efforts and changes in behavioural patterns. The most direct route to improving environmental health is to improve hygiene in all aspects related to water, food and sanitation. People need to know the relations between environmental health and their personal health conditions. They should be sensitised to disease transmission routes and the way they can prevent their families and themselves from infections. An ideal place to communicate this information and behaviour pattern is at school. If children learn to treat their drinking water and food in a hygienically suitable manner and to wash their hands after defecation, they are likely to continue doing so even when they are adults and they will hopefully pass their knowledge on to their children. A further possibility of awareness raising is to initiate community workshops to reach the adult population.

\subsection{Dissemination of more effective water treatment methods and support of use}

The third area of action is related to the people's ignorance on how to handle bad drinking water. Even though about $77 \%$ of the households treat their drinking water, they do not use effective methods. As the prevailing water and sanitation situation cannot change from one day to the other, better education relating to treatment methods is necessary. To adequately treat their water, the slum dwellers need to know the different treatment methods, the way they work, their advantages and limitations. They have to realise that

\begin{tabular}{|c|c|c|c|c|c|c|}
\hline $\begin{array}{l}\begin{array}{l}\text { Education of } \\
\text { family head }\end{array} \\
\text { Monthly } \\
\text { income, in } \\
\text { Indian rupees }\end{array}$ & $\begin{array}{l}\text { 1st-4th } \\
\text { standard } \\
\text { in \% } \\
(\mathrm{n}=78)\end{array}$ & $\begin{array}{l}5 \text { th-7th } \\
\text { standard } \\
\text { in \% } \\
(\mathrm{n}=115)\end{array}$ & $\begin{array}{l}8 \text { th-10th } \\
\text { standard } \\
\text { in \% } \\
(n=74)\end{array}$ & $\begin{array}{c}\text { Complete } \\
\text { graduation } \\
\text { in } \% \\
(n=6)\end{array}$ & $\begin{array}{c}\text { Illiterate } \\
\text { in \% } \\
(n=217)\end{array}$ & $\begin{array}{c}\text { Total } \\
\text { in \% } \\
(\mathrm{n}=490)\end{array}$ \\
\hline$<1500$ & 20.5 & 8.7 & 8.1 & 0.0 & 22.1 & 16.3 \\
\hline $1500-3000$ & 34.6 & 51.3 & 39.2 & 0.0 & 42.9 & 42.4 \\
\hline $3001-5000$ & 16.7 & 25.2 & 31.1 & 16.7 & 21.7 & 23.1 \\
\hline$>5000$ & 28.2 & 14.8 & 21.6 & 83.3 & 13.4 & 18.2 \\
\hline Total & 100.0 & 100.0 & 100.0 & 100.0 & 100.0 & 100.0 \\
\hline
\end{tabular}

Tab. 4: Monthly income by education of family head Monatliches Einkommen in Abhängigkeit des Ausbildungsgrades des Familienoberhauptes

Revenu mensuel selon le niveau d'éducation du chef de famille

Source: University of Basel, Institute of Geography, Urban and Regional Studies, and All India Disaster Mitigation Institute, Ahmedabad, India (2005): Social Science Survey in four slum communities in the City of Bhuj 


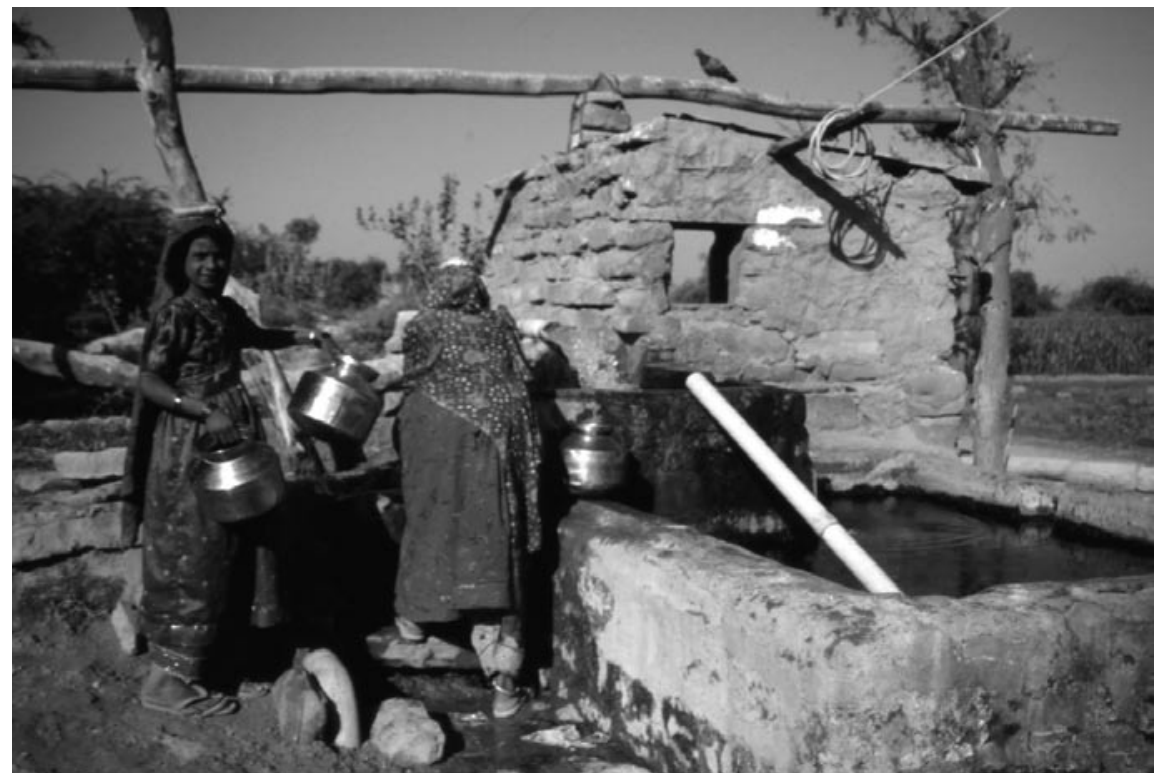

Fig. 2: Well in Jaypragashnagar, City of Bhuj, India

Photo: F. WiELAND Brunnen in Jaypragashnagar, Bhuj, Indien

Puits à Jaypragashnagar, Bhuj, Inde

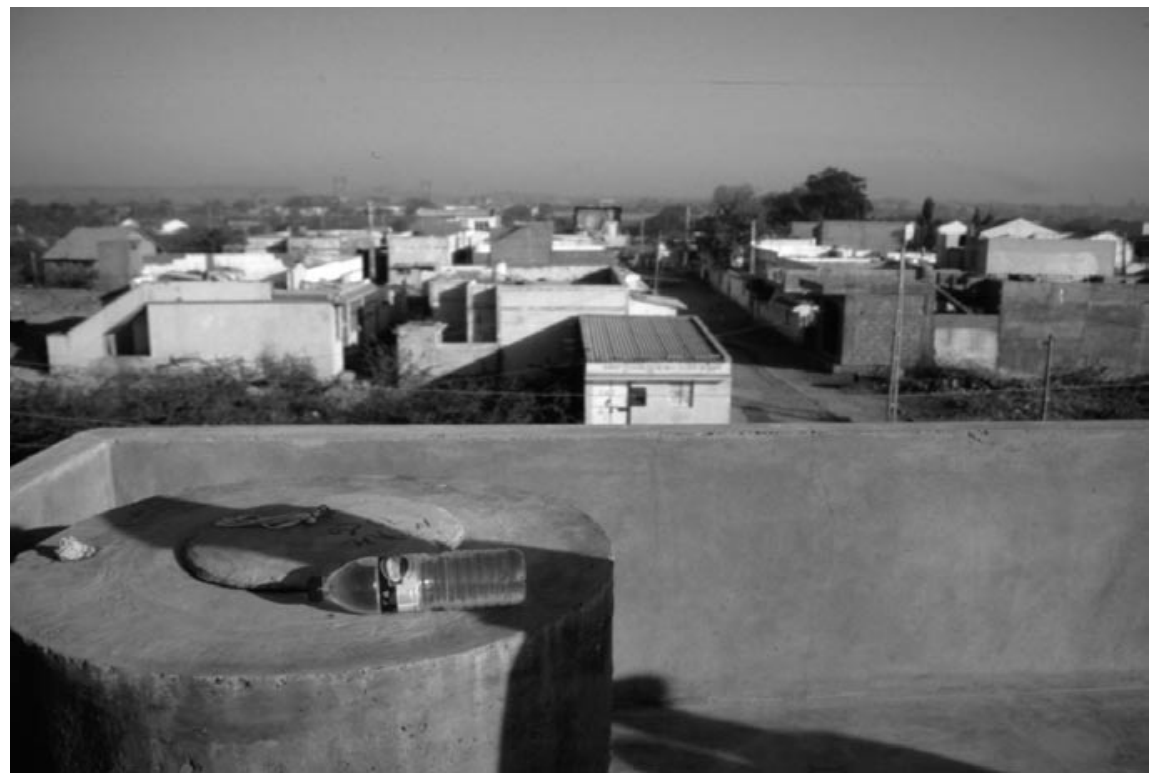

Fig. 3: SODIS application in Jaypragashnagar, City of Bhuj, India

Photo: F. WiELAND SODIS-Anwendung in Jaypragashnagar, Bhuj, Indien Application de SODIS à Jaypragashnagar, Bhuj, Inde 


\begin{tabular}{|c|c|c|c|}
\hline $\begin{array}{l}\text { E.coli } \\
\text { bacteria per } \\
100 \mathrm{ml}\end{array}$ & $\begin{array}{c}\text { Yes } \\
(\mathrm{n}=49) \\
\text { in } \%\end{array}$ & $\begin{array}{c}\text { No } \\
(\mathrm{n}=26) \\
\text { in } \%\end{array}$ & $\begin{array}{c}\text { Total } \\
(\mathrm{n}=75) \\
\text { in } \%\end{array}$ \\
\hline 0 & 18.4 & 7.7 & 14.7 \\
\hline$<10$ & 22.4 & 7.7 & 17.3 \\
\hline $10-70$ & 20.4 & 15.4 & 18.7 \\
\hline $71-100$ & 6.1 & 15.4 & 9.3 \\
\hline $101-200$ & 10.2 & 7.7 & 9.3 \\
\hline $201-450$ & 12.2 & 11.5 & 12.0 \\
\hline $451-1000$ & 4.1 & 11.5 & 6.7 \\
\hline $1001-2000$ & 4.1 & 15.4 & 8.0 \\
\hline$>2000$ & 2.0 & 7.7 & 4.0 \\
\hline Total & 100.0 & 100.0 & 100.0 \\
\hline
\end{tabular}

Tab. 5: Water quality (E.coli) by awareness of relation between hygiene and health

Wasserqualität (E.coli) in Abhängigkeit der Kenntnis der Beziehung zwischen Hygiene und Gesundheit Qualité de l'eau (E.coli) selon la connaissance du rapport entre l'hygiène et la santé

Source: University of Basel, Institute of Geography, Urban and Regional Studies, and All India Disaster Mitigation Institute, Ahmedabad, India (2005): Social Science Survey in four slum communities in the City of Bhuj

an effective treatment of their drinking water is essential for their personal health. Application trainings and support during the weeks of application at home may encourage people to keep on treating their drinking water after the initial experimental phase. The water disinfection methods mentioned above may also be taught in school but more effort should be invested into the education of the adult slum dwellers. It is, of course, beneficial when children learn to treat their drinking water as early as possible but parents, and in particular the women, are normally responsible for the household's water treatment. Their education, therefore, is an essential factor in the propagation of effective water treatment methods.

\section{Acknowledgements}

This research was funded by: Swiss Academy of Sciences Commission for Research Partnerships with Developing Countries, The National Center of Competence in Research North - South Partnerships (NCCR NorthSouth) of the Swiss National Science Foundation and Swiss Agency for Development and Cooperation, and the Niklaus and Bertha Burckhard-Bürgin Foundation.

\section{Literature}

Cairncross, S. \& P. Kolsky (2003): Environmental health and the poor. Our shared responsibility. - Loughborough WELL studies, London: DFIP Publications; www.lboro.ac.uk/well/resources/Publication sAdvocacy $\% 20$ document $\% 20$ - \%20Front $\% 20$ cover $\%$ 20+\%20insides.pdf 10.06.2005.

SANitATION IN DEVELOPING COUNTRIES (SANDEC) (2002): Solar water disinfection. A guide for the application of SODIS. - = SANDEC Report No 06/02, Dübendorf: SANDEC.

Swiss Federal Institute of Aquatic Science And Technology (2005): Solar water disinfection. - www. sodis.ch 06.09.2005.

Water Engineering Development Centre (WEDC) (1999): Running water. More technical briefs on health, water and sanitation. - Edited by RoD, S., London: It Publications; www.lboro.ac.uk/well/resources/technical-briefs/technical-briefs.htm 05.01.2005.

World Health Organization (WHO) (1997): Guidelines for drinking-water quality. Health criteria and other supporting information. - Volume 2, Geneva: WHO Publications; www.who.int/water_sanitation_ health/dwq/gdwq2v1/en/index2.html 03.01.2005.

World Health Organization (WHO) (2001): Water for health. Taking charge. - Geneva: WHO Publications. World Health Organization (WHO) (2002): Environmental health in emergencies and disasters. A practical guide. - Edited by Wisner, B. \& J. AdAms, Geneva: WHO Publications; www.who.int/water_sanitation_health/hygiene/emergencies/emergencies2002/ en/ 22.08.2005.

\section{Summary: Environmental health in slum communi- ties. Analysis of household water quality in four slum communities in the City of Bhuj, India}

The main focus of this study is on water quality in four slum communities in the City of Bhuj, India. In order to determine key variables affecting water quality in surveyed households, the interrelation between household water quality, environmental services, and demographic, social and financial factors was examined. The data used in this study draws on a household survey and the analysis of water samples collected within the targeted slum communities. As faecal contamination of drinking water is a major health risk in small-community supplies, water samples were tested for E.coli bacteria using the membrane-filter method. In a next step, the efficiency of three water treatment methods - filtration through cloth, chlorination and solar disinfection - was tested. Considering various factors, solar disinfection is identified to be the most appropriate method for households in most slum areas. The analysis shows that the water supply and sanitation situation of a household has an effect on that household's drinking water quality. Personal endeavours to 
protect family members from disease can be greatly supported by the provision of safe drinking water, adequate sanitation facilities and wastewater removal systems to every household. Furthermore, it appears that most slum dwellers are not aware of the interdependent relation between environmental health and their personal health conditions. It is therefore argued that awareness raising measures in this area can also be an effective means of supporting personal endeavours to improve household financial situations.

Keywords: environmental health, slum communities, India, drinking water quality tests, household survey

\section{Zusammenfassung: Umwelthygiene in Slums. Eine Analyse der Trinkwasserqualität in Haushalten von vier Slums in Bhuj, Indien}

Der Fokus der Studie umfasst die Qualitätsanalyse der Wasserproben, welche in vier Slums der Stadt Bhuj in Indien genommen wurden. Um Schlüsselvariablen zu ermitteln, welche die Wasserqualität der getesteten Haushalte erklären, wurden die Zusammenhänge zwischen der Wasserqualität und den vorhandenen Wasserund Sanitärmöglichkeiten, demographischen, sozialen und finanziellen Aspekten untersucht. Die Datengrundlage der Studie basiert auf einer Haushaltsbefragung und der Analyse der erhobenen Wasserproben in den vier untersuchten Slums. Das Hauptgesundheitsrisiko bei Trinkwasser von kleinen Gemeinschaftsanschlüssen besteht durch Fäkalverunreinigungen. Die Wasserproben wurden daher, unter Verwendung der Membranfiltermethode, auf E.coli Bakterien untersucht. In einem zweiten Teil der Wasserqualitätsanalyse wurde die Effektivität dreier Wasserreinigungsmethoden - Filtration durch Textilien, Chlorierung und solare Desinfektion - getestet. Unter Einbezug verschiedener Faktoren kann die solare Desinfektion als Methode identifiziert werden, welche für die Anwendung in Slumhaushalten am zweckmässigsten erscheint. Die Untersuchung zeigt, dass die vorhandenen Wasser- und Sanitärmöglichkeiten einen Einfluss auf die Wasserqualität des untersuchten Haushaltes haben. Die persönlichen Anstrengungen zum Schutz der Familienmitglieder vor Krankheiten können durch die Bereitstellung sauberen Trinkwassers, adäquaten sanitären Einrichtungen und eines funktionierenden Abfallentsorgungssystems daher entscheidend unterstützt werden. Die Studie zeigt zudem, dass die meisten Slumbewohner nur ein geringes Bewusstsein bezüglich der Abhängigkeit ihrer eigenen Gesundheit von den Umgebungsbedingungen haben. Bildung und Aufklärung sind daher entscheidend und wichtige Schritte, um Menschen aus Armut zu befreien.
Schlüsselwörter: Umwelthygiene, Slums, Indien, Trinkwasserqualitätstests, Haushaltsbefragung

\section{Résumé: La santé environnementale dans les bidon- villes. Qualité de l'eau potable dans quatre bidonvil- les de Bhuj (Inde)}

L'objectif de l'étude est d'analyser la qualité des prélèvements d'eau dans quatre bidonvilles de Bhuj en Inde. L'article examine en particulier les relations existant entre la qualité de l'eau déterminée par les prélèvements, et les aspects sanitaires, aquifères, démographiques, sociaux et financiers étudiés par enquêtes. Comme le risque principal pour la santé provient de la pollution de l'eau par des matières fécales, des bactéries E.coli ont tout d'abord été recherchées dans les prélèvements d'eau analysés, en utilisant la méthode des filtres à membranes. La fiabilité de trois méthodes de purification de l'eau a ensuite été testée: la filtration par des textiles, la chloration et la désinfection solaire. En prenant en considération différents facteurs, la désinfection solaire peut être considérée comme la plus appropriée pour les ménages des bidonvilles. L'enquête montre que les situations sanitaires et aquifères ont une influence sur la qualité de l'eau des foyers étudiés. La mise à disposition d'eau pure et buvable, d'équipements sanitaires adéquats et d'un système de traitement des déchets approprié peut significativement encourager les efforts individuels entrepris pour protéger les membres de la famille des maladies. L'étude montre en outre que la plupart des habitants des bidonvilles ne sont pas vraiment conscients du fait que leur santé dépend des conditions environnementales. Par voie de conséquence, culture et éducation représentent des moyens importants pour aider les individus à sortir de la pauvreté.

Mots-clés: santé environnementale, bidonvilles, Inde, tests de qualité de l'eau potable, enquête sur les ménages

Dipl.-Geogr. Fiona Wieland, Geographisches Institut, Abteilung Humangeographie / Stadt- und Regionalforschung, Klingelbergstrasse 27, CH-4056 Basel, Schweiz. e-mail: Fiona.Wieland@unibas.ch

\section{Manuskripteingang/received/manuscrit entré le} 30.1.2008

Annahme zum Druck/accepted for publication/accepté pour l'impression: 17.6.2008 